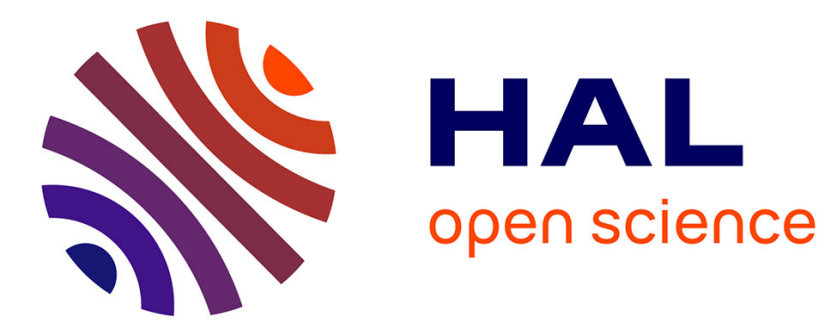

\title{
Proteomics analysis of heterogeneous flagella in brown algae (stramenopiles).
}

Gang Fu, Chikako Nagasato, Seiko Oka, J Mark Cock, Taizo Motomura

\section{To cite this version:}

Gang Fu, Chikako Nagasato, Seiko Oka, J Mark Cock, Taizo Motomura. Proteomics analysis of heterogeneous flagella in brown algae (stramenopiles).. Protist, 2014, 165 (5), pp.662-75. hal-01113862

\section{HAL Id: hal-01113862 \\ https://hal.sorbonne-universite.fr/hal-01113862}

Submitted on 6 Feb 2015

HAL is a multi-disciplinary open access archive for the deposit and dissemination of scientific research documents, whether they are published or not. The documents may come from teaching and research institutions in France or abroad, or from public or private research centers.
L'archive ouverte pluridisciplinaire HAL, est destinée au dépôt et à la diffusion de documents scientifiques de niveau recherche, publiés ou non, émanant des établissements d'enseignement et de recherche français ou étrangers, des laboratoires publics ou privés. 


\title{
Proteomics Analysis of Heterogeneous Flagella in Brown Algae (Stramenopiles)
}

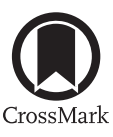

\author{
Gang Fu ${ }^{\mathrm{a}}$, Chikako Nagasato ${ }^{\mathrm{a}}$, Seiko Oka ${ }^{\mathrm{b}}$, J. Mark Cock ${ }^{\mathrm{c}}$, and Taizo Motomura ${ }^{\mathrm{a}, 1}$ \\ aMuroran Marine Station, Field Science Center for Northern Biosphere, Hokkaido \\ University, Muroran 051-0013, Hokkaido, Japan \\ ${ }^{b}$ Instrumental Analysis Division, Equipment Management Center, Creative Research \\ Institution, Hokkaido University, Sapporo 001-0021, Hokkaido, Japan \\ 'University Pierre et Marie Curie and Centre National de la Recherche Scientifique, Unité \\ Mixte de Recherche 7139, Laboratoire International Associé Dispersal and Adaptation in \\ Marine Species, Station Biologique de Roscoff, 29682 Roscoff Cedex, France
}

Submitted May 26, 2014; Accepted July 22, 2014

Monitoring Editor: George B. Witman

Flagella are conserved organelles among eukaryotes and they are composed of many proteins, which are necessary for flagellar assembly, maintenance and function. Stramenopiles, which include brown algae, diatoms and oomycetes, possess two laterally inserted flagella. The anterior flagellum (AF) extends forward and bears tripartite mastigonemes, whilst the smooth posterior flagellum (PF) often has a paraflagellar body structure. These heterogeneous flagella have served as crucial structures in algal studies especially from a viewpoint of phylogeny. However, the protein compositions of the flagella are still largely unknown. Here we report a LC-MS/MS based proteomics analysis of brown algal flagella. In total, 495 flagellar proteins were identified. Functional annotation of the proteome data revealed that brown algal flagellar proteins were associated with cell motility, signal transduction and various metabolic activities. We separately isolated AF and PF and analyzed their protein compositions. This analysis led to the identification of several AF- and PF-specific proteins. Among the PF-specific proteins, we found a candidate novel blue light receptor protein involved in phototaxis, and named it HELMCHROME because of the steering function of PF. Immunological analysis revealed that this protein was localized along the whole length of the PF and concentrated in the paraflagellar body.

(c) 2014 Elsevier GmbH. All rights reserved.

Key words: Blue light receptor; brown algae; creatine kinase; flagella; phototaxis; proteomics.

\section{Introduction}

Flagella or cilia are almost ubiquitous organelles in a diverse range of eukaryotic cells and substantial studies have revealed their versatile roles in cellular motility and signal perception (Cavalier-Smith

\footnotetext{
${ }^{1}$ Corresponding author; fax +81143224135

e-mail motomura@fsc.hokudai.ac.jp (T. Motomura).
}

2002; Davenport and Yoder 2005). The structure of the flagellum is evolutionarily conserved (Carvalho-Santos et al. 2011; Mitchell 2007) and for a motile flagellum, its core structure is a "9+2" axoneme comprising nine outer doublet microtubules and central pair of microtubules. Various macromolecular components such as outer and inner dynein arms, radial spokes and central pair projections, are periodically organized along the microtubule-based axoneme and 
responsible for flagellar beating (Nicastro et al. 2005). The axoneme extends from the basal bodies beyond the cell surface and is covered by flagellar membrane, which is continuous with the plasma membrane but has different protein and lipid compositions relating to the sensory function of flagella (Pazour and Bloodgood 2008). In addition to the axoneme structure, an intraflagellar transport (IFT) system is also present in the compartment enclosed by the flagellar membrane and the outer doublet microtubules (Kozminski et al. 1993). The IFT consists of anterograde and retrograde protein complexes responsible for flagellar assembly and maintenance (Rosenbaum and Witman 2002). Given the functional diversity and structural complexity, it is not surprising that hundreds of proteins are required for the correct assembly, maintenance and functioning of flagella. As a result of a combination of bioinformatics, genomics and proteomics analyses of the flagella of model organisms, our understanding of the flagellar proteins has greatly advanced in the last decade (Gherman et al. 2006; Inglis et al. 2006).

The stramenopiles constitute a large independent group among eight eukaryotic lineages, and contain diverse organisms from unicellular parasitic flagellates to giant kelp, including five non-photosynthetic subgroups (such as oomycetes and labyrinthulomycetes) and eleven photosynthetic ones (such as brown algae and diatoms) (Baldauf 2008). Stramenopiles are characterized by possessing an anterior flagellum (AF) with tripartite mastigonemes in the motile stage (gametes and zoospores). An alternative name for the stramenopiles is the heterokonts, because most species within this group often have a shorter, smooth posterior flagellum (PF) in addition to the AF. Functionally, the AF generates propulsive force through waveform bending to power the cell forward swimming motility and the PF exhibits rapid lateral beating to steer the swimming direction (Geller and Müller 1981; Matsunaga et al. 2010).

The brown algae (Phaeophyceae) are a major group within the stramenopiles that are mostly found in marine habitats, and distributed worldwide. During a typical brown algal life cycle, the two heterogeneous flagella (AF and PF) are observed in the unicellular reproductive cells (gametes and zoospores). As one of the most important organelles in brown algae, a great deal of attention has been paid to flagella and their ultrastructural characters have been studied extensively (Henry and Cole 1982a, b; Maier 1997a, b; Manton and Clarke 1951; Manton et al. 1953). The flagella are also critical structures when considering phylogenetic relationships within the brown algae (Clayton 1989; O'Kelly 1989). However, the protein composition of brown algal flagella remains largely unknown, probably owing to the difficulty in isolating high quality brown algal flagella in sufficient quantity and, until recently, the lack of a brown algal genome database to underpin the flagellar protein analysis.

Although the genome sequence of the model brown alga Ectocarpus siliculosus has become available (Cock et al.2010), proteomics analysis of its flagella is hampered by limitations in the amount of this organelle that can be isolated. In this study, we used plurizoids of Colpomenia bullosa collected from the field to carry out flagellar proteomics analysis. Light and electron microscopy showed that plurizoids of Colpomenia and Ectocarpus are structurally similar. Moreover, the two species both belong to the Ectocarpales according to traditional brown algal classification criteria (Guiry and Guiry 2014), and a multi-marker based phylogenetic analysis of 72 brown algal taxa revealed that Colpomenia is phylogenetically close to Ectocarpus (Silberfeld et al. 2010). These data encouraged us to use the genome sequence of $E$. siliculosus as a database to identify $C$. bullosa flagellar proteins. Here, we present the result of LC-MS/MS based proteomics analysis of isolated flagella from the latter species. We also identified several AF- and PF-specific proteins. A candidate novel blue light receptor protein responsible for phototaxis of brown algal swarmers is also discussed.

\section{Results and Discussion}

\section{Heterogeneity and Isolation of Brown Algal Flagella}

The flagellated cells of $C$. bullosa and $E$. siliculosus are around $5 \times 7 \mu \mathrm{m}$ in size and bear two heterogeneous flagella in different lengths (Fig. 1A). Under blue-violet (BV, 400-440 nm) irradiance, the PF emits green autofluorescence (Fig. 1B), which is thought to be associated with a flavin-like protein (Kawai 1988). Both flagella are laterally inserted into the cell body (Fig. 1C) and the basal part of the $\mathrm{PF}$ is closely associated with the eyespot (Fig. 1D). This swollen basal part of the PF, the paraflagellar body (Fig. 1A, B, D), is filled with crystalized materials and electron dense materials (Fig. 1E) (Fu et al. 2013). The AF is decorated with tripartite mastigonemes on the flagellar surface (Fig. 1F). The axonemes of both flagella display the typical "9+2" microtubular arrangement, however, the two flagella exhibit distinct beating patterns when cells 


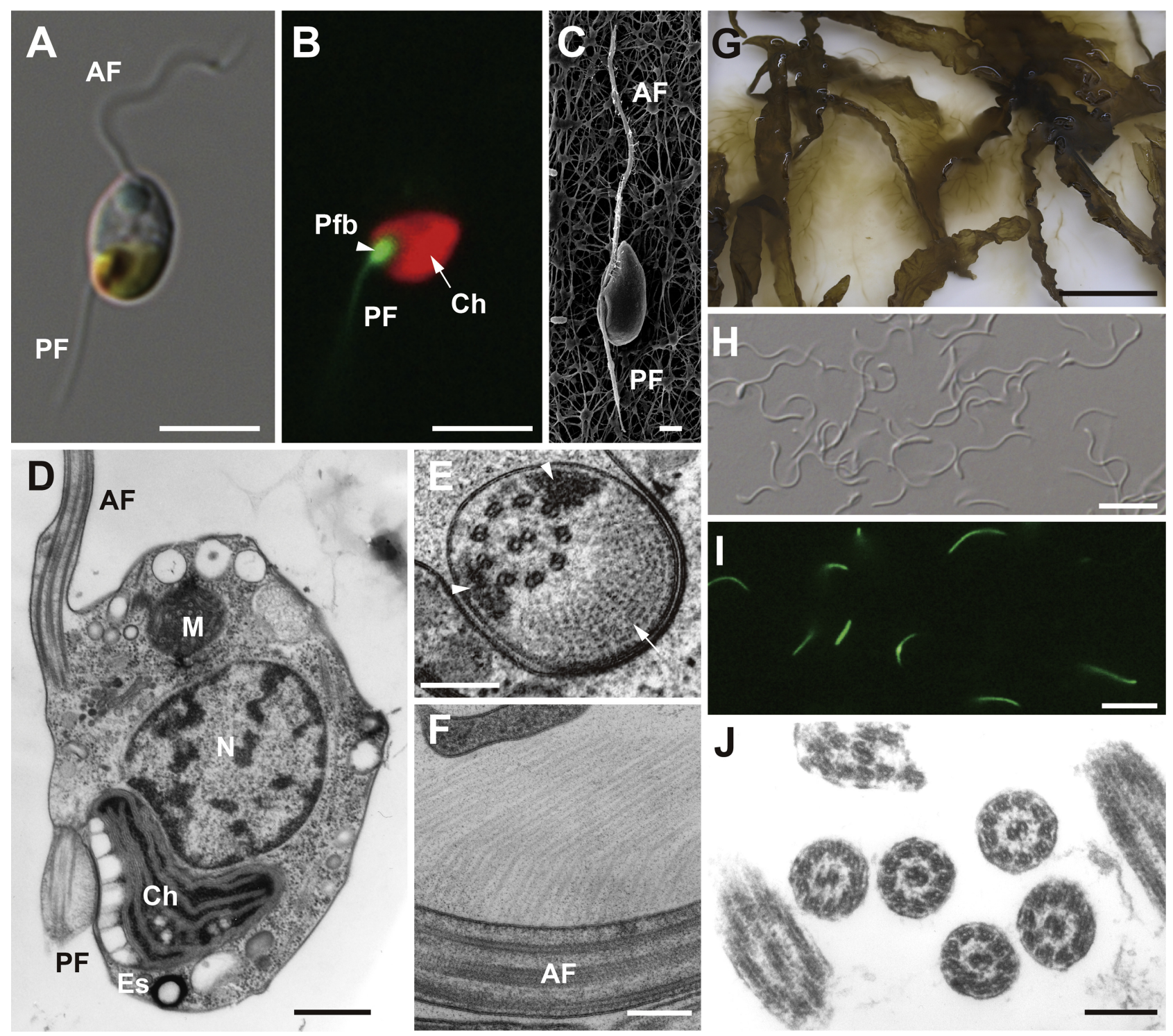

Figure 1. Swarmers and heterogeneous flagella of Colpomenia bullosa and Ectocarpus siliculosus. A: DIC image of $C$. bullosa plurizoid bearing a long anterior flagellum (AF) and a short posterior flagellum (PF). B: Fluorescent image of the same cell in A under BV light (400-440 nm). Green autofluorescence of PF and red autofluorescence of chloroplast (arrow) are observed. Note that green autofluorescence accumulates in the paraflagellar body (arrowhead) of the PF. C: SEM image of an E. siliculosus gamete. Note that two flagella are laterally inserted into the cell body. D: TEM image of $C$. bullosa plurizoid. Note that paraflagellar body is closely associated with eyespots. E: Cross-section view of the paraflagellar body of the PF. Crystalized material (arrow) and electron dense material (arrowheads) could be observed around the axoneme. F: TEM image of mastigonemes on the surface of the AF. G: Release of numerous plurizoids from thalli of $C$. bullosa. H: DIC image of isolated flagella. I: Fluorescent image of the same sample as $\mathrm{H}$. Note that the green autofluorescence of PF can still be observed. J: TEM image of isolated flagella. Both ruptured flagella and intact ones can be observed.

AF, anterior flagellum; Ch, chloroplast; Es, eyespot; M, mitochondria; N, nucleus; PF, posterior flagellum; Pfb, paraflagellar body. Scale bars represent $5 \mu \mathrm{m}$ in (A) and (B); $1 \mu \mathrm{m}$ in (C); $500 \mathrm{~nm}$ in (D); $200 \mathrm{~nm}$ in (E), (F) and $(\mathrm{J}) ; 5 \mathrm{~cm}$ in $(\mathrm{G}) ; 10 \mu \mathrm{m}$ in $(\mathrm{H})$ and $(\mathrm{I})$. 
swim; the AF exhibits flexible, undulate beats and the PF shows rigid, lateral beats (Supplementary Material Movie S1).

Numerous plurizoids from plurilocular zoidangia were released from thalli of $C$. bullosa collected from the field (Fig. 1G). Flagella were isolated (Fig. $1 \mathrm{H}$ ) from cell bodies with a flagellar isolation buffer containing $5 \mathrm{mM}$ EGTA. It was noteworthy that the green autofluorescence of the isolated PF could still be observed under BV light (Fig. 1I), indicating the potential integrity of the prepared proteins. An electron micrograph of isolated flagellar fractions (Fig. 1J) showed that the preparations were enriched in flagellar fragments.

\section{Identification of Brown Algal Flagellar Proteins}

Flagellar proteins were separated by SDS-PAGE. The gel was then cut into $1 \mathrm{~mm}$ pieces and the proteins were digested with trypsin. The diluted peptides were subjected to LC-MS/MS analysis. The sequences of the identified peptides were compared with the translated $E$. siliculosus genome database for protein identification. Two additional independent experiments were carried out using the same protocol. Based on the data obtained from these three replicates, proteins identified by two or more peptides and present in at least two replicates were considered as brown algal flagellar proteins. This approach allowed the identification of 495 non-redundant proteins that constituted the C. bullosa flagellar proteome (CbFP) (Supplementary Material Table S1). Following comparison with the annotations of the E. siliculosus genome, nearly $53 \%$ of the identified flagellar proteins remained functionally unknown. In order to compile a protein list with more comprehensive annotations, we compared the CbFP with the Gene Ontology (GO) database and recovered the matched GO terms for the three major categories: molecular function, biological process and molecular component (Supplementary Material Fig. S1). "ATP binding", "microtubule motor activity" and "calcium ion binding" were shown as the prominent groups in the molecular function category. In the other two categories, "microtubule-based movement" and "protein phosphorylation", along with "dynein complex" and "microtubule" were prevalent in the biological process and the cellular component category, respectively. These findings together with the GO annotation for each protein in CbFP (Supplementary Material Table S1) indicate that not only the conventional functions (e.g., binding and hydrolysis of ATP to produce energy for microtubule sliding, sensing calcium-ion concentrations to regulate flagellar beat pattern) but also probably novel flagellar protein activities exist in brown algae. One of such activities is related to an ATP-regenerating system for maintaining nucleotide concentrations within flagella, which have been reported in diverse model organisms to meet this organelle's highenergy consumption demand. Ginger et al. (2008) described three metabolic enzymes/ pathways, adenylate kinase (ADK), glycolytic enzymes and creatine kinase $(\mathrm{CK})$ that could generate ATP in protist flagella. In brown algal flagella, we also found candidate proteins involved in glycolysis and creatine kinase activity. There were three late glycolytic pathway enzymes, glyceraldehyde-3phosphate dehydrogenase (CBJ29997.1), enolase (CBN78148.1) and pyruvate kinase (CBJ32589.1) in CbFP. Despite the fact that the detailed process of flagellar glycolysis remains elusive, several glycolytic enzymes have also been reported in the flagella of Chlamydomonas (Pazour et al. 2005). Among the enzymes, enolase was shown to be an axonemal subunit of the central pair complex (Mitchell et al. 2005). Although CK activities were found to play essential roles in energy homeostasis within the flagellar apparatus of sea urchin (Tombes et al. 1987; Wothe et al. 1990), it is surprising that a CK protein (CBN74482.1) was identified in CbFP. In sea urchin sperm, two isozymes of $\mathrm{CK}$ in the mitochondrion and the sperm flagellum were shown to mediate the phosphorylcreatine shuttle between the two intracellular compartments (Tombes and Shapiro 1985). There are also two predicted isozymes of $\mathrm{CK}$ in the genome of the brown alga E. siliculosus (Cock et al. 2010) and the identification of one in the CbFP suggests that a similar ATP metabolic activation may exist between the cell body and the flagella.

\section{Orthologous Proteins Encoded in Other Eukaryotic Genomes}

Comparative, genome-wide analysis of flagellated and non-flagellated organisms has identified several protein datasets associated with flagella or basal bodies (Avidor-Reiss et al. 2004; Judelson et al. 2012; Li et al. 2004). Following the same strategy, we carried out a stringent reciprocal BLAST analysis by comparing CbFP sequences with the genome-encoded proteomes of eighteen selected eukaryotic species to identify putative orthologous proteins of CbFP (Supplementary Material Table S2). As expected, species lacking a flagellated stage in their life cycle tended to possess fewer orthologous proteins than species 

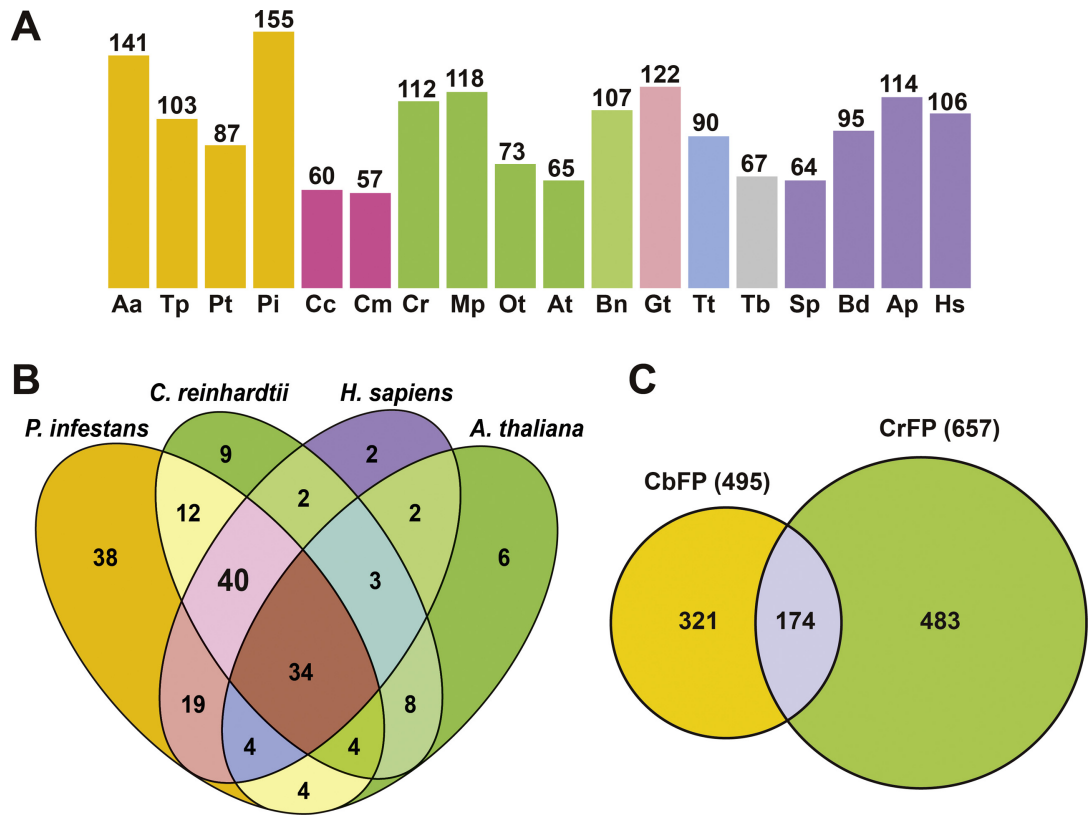

Figure 2. Conservation of CbFP in flagellated and non-flagellated organisms. A: Number of CbFP orthologous proteins found in the genome of eighteen organisms by reciprocal BLAST. Aa, Aureococcus anophagefferens; Tp, Thalassiosira pseudonana; Pt, Phaeodactylum tricornutum; Pi, Phytophthora infestans; Cc, Chondrus crispus; Cm, Cyanidioschyzon merolae; $\mathrm{Cr}$, Chlamydomonas reinhardtii; Mp, Micromonas pusilla; Ot, Ostreococcus tauri; At, Arabidopsis thaliana; Bn, Bigelowiella natans; Gt, Guillardia theta; Tt, Tetrahymena thermophila; Tb, Trypanosoma brucei; Sp, Schizosaccharomyces pombe; Bd, Batrachochytrium dendrobatidis; Sp, Strongylocentrotus purpuratus; Hs, Homo sapiens. B: Comparison of CbFP orthologous proteins in three flagellated organisms $P$. infestans, $C$. reinhardtii, $H$. sapiens and one non-flagellated organism $A$. thaliana. The forty proteins that are conserved only in flagellated organisms (see Supplementary Table S3). C: Comparison of CbFP with $C$. reinhardtii flagella proteome (CrFP). 174 proteins of CbFP have homologs in CrFP (see Supplementary Material Table S4).

that possess flagella (Fig. 2A). Among the four stramenopile species, Phytophthora infestans, an oomycete species developing " $9+2$ " axonemes, had most orthologs. The centric diatom Thalassiosira pseudonana, whose sperm flagella possess a "9+0" axoneme (Idei et al. 2013), has no radial spoke or central pair associated protein orthologs. The pennate diatom Phaeodactylum tricornutum that lacks flagellated cells shares fewest orthologous proteins of CbFP among the investigated stramenopiles species. Although a flagellate stage of the pelagophyceaen alga Aureococcus anophagefferens has not been reported, recent research on pix proteins and the RJL family of small GTPases indicated that there might be flagellated cells in its life cycle (Elias and Archibald 2009; Woodland and Fry 2008). The occurrence of flagellated cells of $A$. anophagefferens was supported in the present study because $A$. anophagefferens had the second largest number of CbFP orthologs in the genome. For the non-stramenopiles species, however, the African sleeping sickness parasite
Trypanosoma brucei appeared to be an exception to the contention that flagellated species possess a greater number of CbFP orthologs. The low number of orthologues found in this species could be explained by the results of previous studies, which showed that in a compiled inventory of kinetoplastid flagellar proteins, $43 \%$ sequences were specific to this phylogenetic group perhaps due to their unique paraflagellar rod structure (Baron et al. 2007; Broadhead et al. 2006; Ralston et al. 2009).

The orthologs found in non-flagellated organisms indicated that these proteins, which include kinases and metabolic enzymes, might play roles in both flagella and cytoplasm. To identify proteins that are highly conserved only in flagella, we analyzed 40 CbFP orthologous proteins shared in flagellated $P$. infestans, $C$. reinhardtii and human, but not in $A$. thaliana (Fig. 2B). Of these proteins, 19 (48\%) were essential components of the flagellar axoneme or the IFT system, and $10(25 \%)$ had putative functions in signal transduction or metabolism pathways. However, the function of $11(27 \%)$ of these 
proteins still remained unclear (Supplementary Material Table S3). It is interesting that a molecular chaperon protein, Hsp70 (CBJ32839.1), was conserved in the flagellated species but not in $A$. thaliana. The first identification of Hsp70 in flagella was reported in Chlamydomonas (Bloch and Johnson 1995), after which a further exploration of molecular chaperons suggested their wide distribution as flagellar components (Stephens and Lemieux 1999). Despite the large number of HSP family members, the only CbFP Hsp70 ortholog in Chlamydomonas was HSP70A (XP_001701326) (Supplementary Material Table S2), which was reported to be localized in flagella (Shapiro et al. 2005). This indicates that some flagellar Hsp chaperons might have unique functions in flagellar assembly and maintenance.

In addition, we subjected the CbFP to a BLAST (E-value was set as $\leq 1 \mathrm{e}^{-10}$ ) analysis using $657 \mathrm{C}$. reinhardtii flagellar proteins (Pazour et al. 2005, available at http://labs.umassmed.edu/chlamyfp/) as query sequences to compare the two flagellar proteomes (Fig. 2C). One hundred and seventyfour of the CbFP proteins had homologs in the C. reinhardtii flagellar proteome (CrFP), most of them being known structural and motor proteins (Supplementary Material Table S4), indicating the common characters of flagella in these two algal species. However, the large proportion (321) of the $\mathrm{CbFP}$ that lacks homologs in the CrFP reflects the significant differences between them. These include obvious structural differences, such as flagellar length, mastigoneme and paraflagellar body, and perhaps distinct sensory functions of the flagella. For example, transduction of light stimuli in C. reinhardtii is triggered from cytoplasmic channelrhodopsins to flagellar axonemes (Govorunova et al. 2004; Okita et al. 2005), whereas in brown algae the photoreceptor protein is likely located at the PF (Flores-Moya et al. 2002; Kawai 1988; Kawai et al. 1990; Müller et al. 1987), which implies a different light-induced signaling cascade within the flagella. Therefore, the list of 321 proteins in the $\mathrm{CbFP}$ that lack CrFP homologs provide potential candidates to explore the proteins associated with structural and functional differences between brown and green algal flagella.

\section{Conservation of Flagellar Disease Proteins in CbFP}

Increasing evidence supports that flagellar dysfunction causes severe vertebrate diseases (Bisgrove and Yost 2006; Fliegauf et al. 2007; Marshall 2008; Marshall and Nonaka 2006).
Since flagella are highly conserved organelles among eukaryotes, proteins involved in many of these flagella-related disorders could also be detected in non-vertebrate organisms such as C. reinhardtii (Pazour et al. 2005). Likewise, we identified homologs of such proteins in CbFP and all of them had a matched sequence in the human genome when analyzed by BLAST (Table 1). Defects in these proteins result in a broad range of vertebrate diseases, including dysfunction of the male reproductive system, hydrocephalus, Bardet-Biedl Syndrome, polycystic kidney disease and others (see references in Table 1). The comparison between CbFP and CrFP (Supplementary Material Table S4) showed that homologues of the disease-related proteins identified in CbFP were also conserved in Chlamydomonas flagella. Conservation of flagellar disease proteins in nonvertebrate organisms indicates that these proteins are essential flagellar components relating to its fundamental structure and function. For example, in addition to IFT and dynein arm proteins, homologues of hydin and Spag16 are also axonemal proteins localized at the central pair apparatus (Lechtreck and Witman 2007; Zhang et al. 2002).

\section{Independent Proteomics Analysis of the AF and the PF}

It would be intriguing and important to identify AFand PF-specific proteins to explain their morphological and functional heterogeneities at the molecular level in brown algae. We have developed an effective procedure to separately isolate $A F$ and $P F$ (Fig. 3A-D). One-dimensional gel electrophoresis confirmed that several bands limited to AF or PF could be detected (Fig. 3E). We also performed 2$D$ analysis of the isolated flagellar proteins, which yielded over 20 specific spots associated with each flagellar preparation (Supplementary Material Fig. S2). Utilizing these flagellar fractions, we attempted to identify AF- and PF-specific proteins by LCMS/MS.

Three and fourteen proteins which were specific to AF and PF, respectively, were identified by two or more peptides (Supplementary Material Table S5). The identification of a mastigoneme-associated protein (CBJ28331.1) in the AF proteome but not in the PF indicates that these proteins are likely to be bona fide flagella-specific proteins. A giant protein (CBJ30163.1) annotated as "similar to connectin/titin isoform N2-B" was identified in the AF-specific dataset. It has an extraordinary huge predicted molecular weight of 1,822 $\mathrm{kDa}$ and at the $\mathrm{N}$-terminal, a signal peptide and 
Table 1. Vertebrate flagellar/ciliary disease proteins conserved in CbFP.

\begin{tabular}{|c|c|c|c|c|c|}
\hline Accession number & Protein & $\begin{array}{l}\text { Diseases or } \\
\text { signaling }\end{array}$ & $\begin{array}{l}\text { Homologues in } \\
\text { human* }\end{array}$ & E-value & Reference \\
\hline CBJ49075.1 & Hydin & Hydrocephalus & NP_001257903.1 & $9 e-131$ & $\begin{array}{l}\text { Davy and } \\
\text { Robinson } \\
2003\end{array}$ \\
\hline CBJ25983.1 & PACRG & Azoospermia & DAA02134.1 & $4 e-87$ & $\begin{array}{l}\text { Lorenzetti } \\
\text { et al. } 2004\end{array}$ \\
\hline CBN79843.1 & PF20/Spag16 & $\begin{array}{l}\text { Spermatogenesis; } \\
\text { Male sterility }\end{array}$ & AAH25379.1 & $1 e-143$ & $\begin{array}{l}\text { Nagarkatti- } \\
\text { Gude et al. } \\
\text { 2011; Zhang } \\
\text { et al. } 2004\end{array}$ \\
\hline CBJ28197.1 & ARL6 & $\begin{array}{l}\text { Bardet-Biedl } \\
\text { Syndrome }\end{array}$ & NP_115522.1 & $9 e-29$ & $\begin{array}{l}\text { Fan et al. } \\
2004\end{array}$ \\
\hline CBN80096.1 & PKA & $\begin{array}{l}\text { Hedgehog } \\
\text { signaling }\end{array}$ & XP_005270029.1 & $5 e-65$ & $\begin{array}{l}\text { Tuson et al. } \\
2011\end{array}$ \\
\hline CBN75228.1 & NIMA kinase & PKD & AAH15147.1 & $8 e-86$ & $\begin{array}{l}\text { Mahjoub } \\
\text { et al. } 2005\end{array}$ \\
\hline CBJ27174.1 & PP1 & Spermatogenesis & CAA52169.1 & 0 & $\begin{array}{l}\text { Varmuza } \\
\text { et al. } 1999\end{array}$ \\
\hline
\end{tabular}

Abbreviations: ARL, ADP-ribosylation factor protein; PACRG, parkin co-regulated gene; PKA, protein kinase A; PKD, polycystic kidney disease; PP1, protein phosphatase 1.

*BLASTP was performed (with the e-value cutoff of $\leq 1 \mathrm{e}-10$ ) for searching the homologues in human genome database.
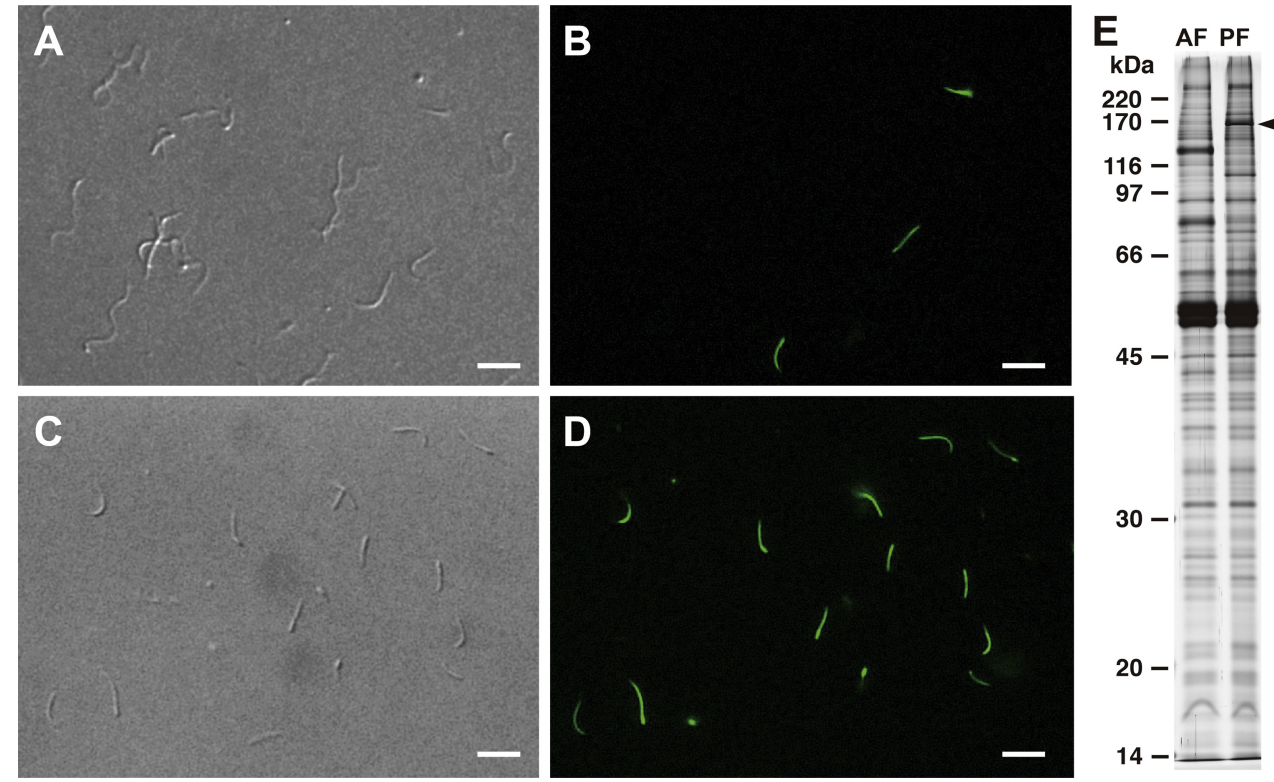

Figure 3. Separate isolation of the AF and the PF from C. bullosa plurizoids. A: DIC image of isolated AF. B: Fluorescent image of the same sample as in A. A few (15\%) PF contaminants that emit fluorescence can be observed. C: DIC image of isolated PF. D: Fluorescent image of the same sample as in C. All the isolated flagella were PF. E: SDS-PAGE of AF- and PF- specific proteins. Arrowhead indicates one PF-specific band, which corresponds to the HELMCHROME protein. Scale bars represent $10 \mu \mathrm{m}$.
D

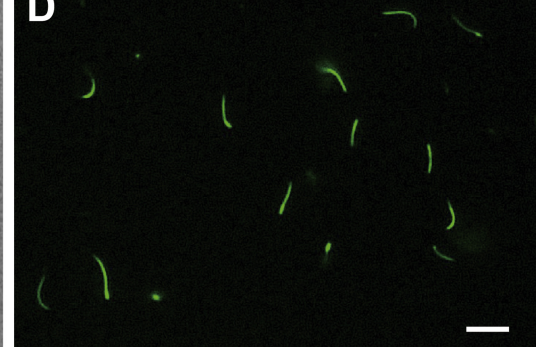


one transmembrane helix could be predicted. The domain architecture of this protein includes multiple copies of the "Fibronectin type III" domain, three "PA14" domains and three "Filamin/ABP280 repeat" domains, which are widely distributed in scaffold proteins involved in ligand binding activity (de Groot and Klis 2008; Feng and Walsh 2004; Koide et al. 1998). This connectin-like protein is likely associated with mastigoneme structures in the AF, and this is consistent with our previous study (Fu et al. 2013) that connecting structures linking mastigoneme and flagellar axoneme could be observed with electron tomography.

Existence of PF-specific, signal transduction proteins might be likely related to locomotive reaction of PF upon stimulations. For example, pheromonestimulated male gametes of Ectocarpus increased the beat frequency of PF, which subsequently changed the swimming direction of the male gamete for approaching to the female gamete (Geller and Müller 1981). PF also performed one to several rapid lateral beats upon light stimulation (Matsunaga et al. 2010), indicating that PF also plays essential roles in phototaxis of brown algal swarmers.

\section{HELMCHROME, a Candidate Novel Blue Light Receptor for Phototaxis}

In brown algae, although the photoreceptor protein participating in phototaxis has not been identified, studies concerning the phototaxis of brown algal swarmers have provided significant evidence to facilitate identification of the light receptor protein. Action spectrum analyses of brown algal swarmers indicate that the photoreceptor pigment is a flavin and thus the photoreceptor is a flavoprotein (Flores-Moya et al. 2002; Kawai 1988; Kawai et al. 1990; Müller et al. 1987). Kawai et al. (1996) further showed that this flavin substance was flavin mononucleotide (FMN). When excited by BV light, the binding of FMN to the PF causes the emission of green autofluorescence, suggesting that the photoreceptor is specifically localized at the PF. Importantly, the autofluorescence was only detected in zoospores and gametes that exhibited phototaxis (Kawai 1992; Müller et al. 1987). In addition, the paraflagellar body and eyespot appear to be involved in phototaxis since they are lacking in non-phototactic brown algal swarmers (Kawai and Inouye 1989). A recent study aimed at identifying the nature of the photoreceptor (Fujita et al. 2005) reported an Old Yellow Enzyme homolog protein at the PF of Scytosiphon lomentaria. However, the homologous protein (CBJ27572.1) in CbFP was identified in both the AF and the PF proteome in our study and the existing annotations of its molecular function (relating to oxidoreductase activity) also suggest that it might not be the real photoreceptor. Here we report a candidate novel blue light receptor in the PF-specific proteome and we named it "HELMCHROME" (accession number CBJ26132.1) due to its proposed function in steering the swimming direction of swarmers during phototaxis.

Several genes that are predicted to encode photoreceptor proteins such as aureochrome, phytochrome, cryptochrome and cry-DASH, have been detected in the $E$. siliculosus genome (Cock et al. 2010), but none of them were identified in the CbFP or the PF-specific proteome (Supplementary Table S1). HELMCHROME was specifically identified in PF with high confidence and it is a multidomain protein with a predicted molecular weight of $168 \mathrm{kDa}$. The domain architecture of HELMCHROME (Fig. 4A) showed no homology to any protein when searched with the conserved domain architecture retrieval tool (Geer 2002). The protein consists of two homologous regions that are tandemly arranged from $\mathrm{N}$-terminal to $\mathrm{C}$-terminal. Each region comprises a Regulator of G-protein Signaling domain (RGS) and two Light-OxygenVoltage sensing domains (LOV) (Fig. 4A). The LOV domain is a member of the Per-ARNT-Sim (PAS) superfamily and is a photoresponsive signaling module that can non-covalently bind FMN via 911 conserved amino acid residues (Crosson and Moffat 2001; Crosson et al. 2003; Losi and Gärtner 2012). It is noteworthy that the LOV1 and LOV3 domains of HELMCHROME possess all the 11 conserved amino acid residues required for FMNbinding (Fig. 4B), however, the cysteine residue that is critical for formation of a covalent adduct between the residue and flavin atom $\mathrm{C}$ (4a) (Crosson and Moffat 2001) is not conserved in LOV2 and LOV4 (Fig. 4B). We tentatively assume that the LOV1 and LOV3 are capable of FMN-binding while the other two LOV domains are not. The two RGS domains share sequence similarity of $62 \%$ over 120 amino acids and their GTP hydrolysis activities imply that heterotrimeric $G$ protein might be involved in the signal transduction pathways in phototaxis of brown algal motile cells.

To confirm the subcellular localization of HELMCHROME, we raised polyclonal antibody against a part of the protein (Fig. 4A). Western blot analysis showed that the antibody detected a band of $170 \mathrm{kDa}$ in the PF-enriched fraction (Fig. 4C). Consistent with the observation of green autofluorescence, immunofluorescence microscopy 
A

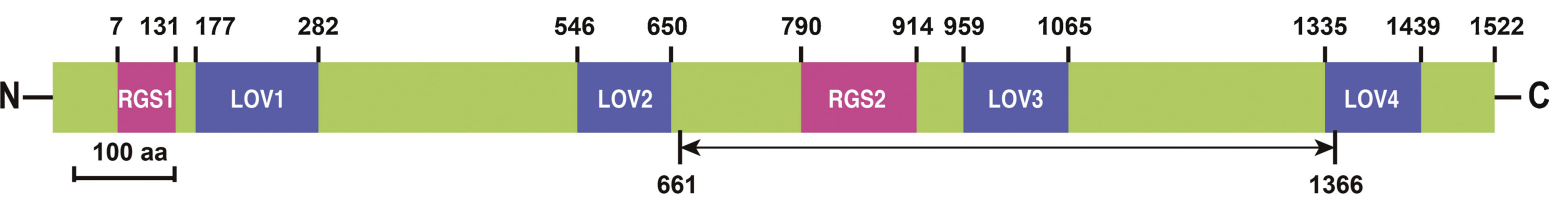

B

$$
\frac{1}{m} \mathbf{r}
$$

II

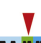

17

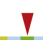

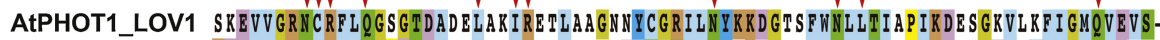

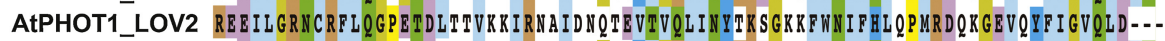
AtPHOT2_LOV1 SREIVGRNCRPLQGPDTDKNEVARIRDCVKNGKSYCGRLLNYKKD GTPFWNLLTVIPIKDDQGNTIKPIGUQVEVSATPHOT2_LOV2 REEILGRNCRPLQGPET QATVQRIRDAIRDQREITVQLINYTKSGKRPWNLFHLPMRDQRGELQYFIGVLLD-.VFAUREO1_LOV LDQIL GRNCRPLQGPBTDPRAVDRIRNAITRGVDTSVCLLNYRQDGTTFWNLFPVAGLRDSRGNIVNYVGVQSKVSE

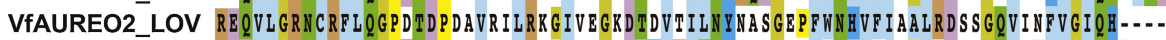

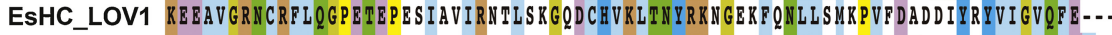
EsHC_LOV3 REEAVGRICRPLQGPETEPBSIAVIRNTLSRGQDCHVRLTNYRKNGERPQNLLSUKPVPDGDNIYRYVIGVQPEI--

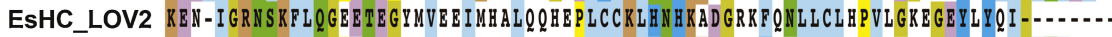
ESHC_LOV4 KEN-IGRNSKPLQGPMIEGIUVERIVESLRHADPLPCKLQNHKPDGSVYOLCLCLTPVFNVDGEYKIQIGCQVD -..
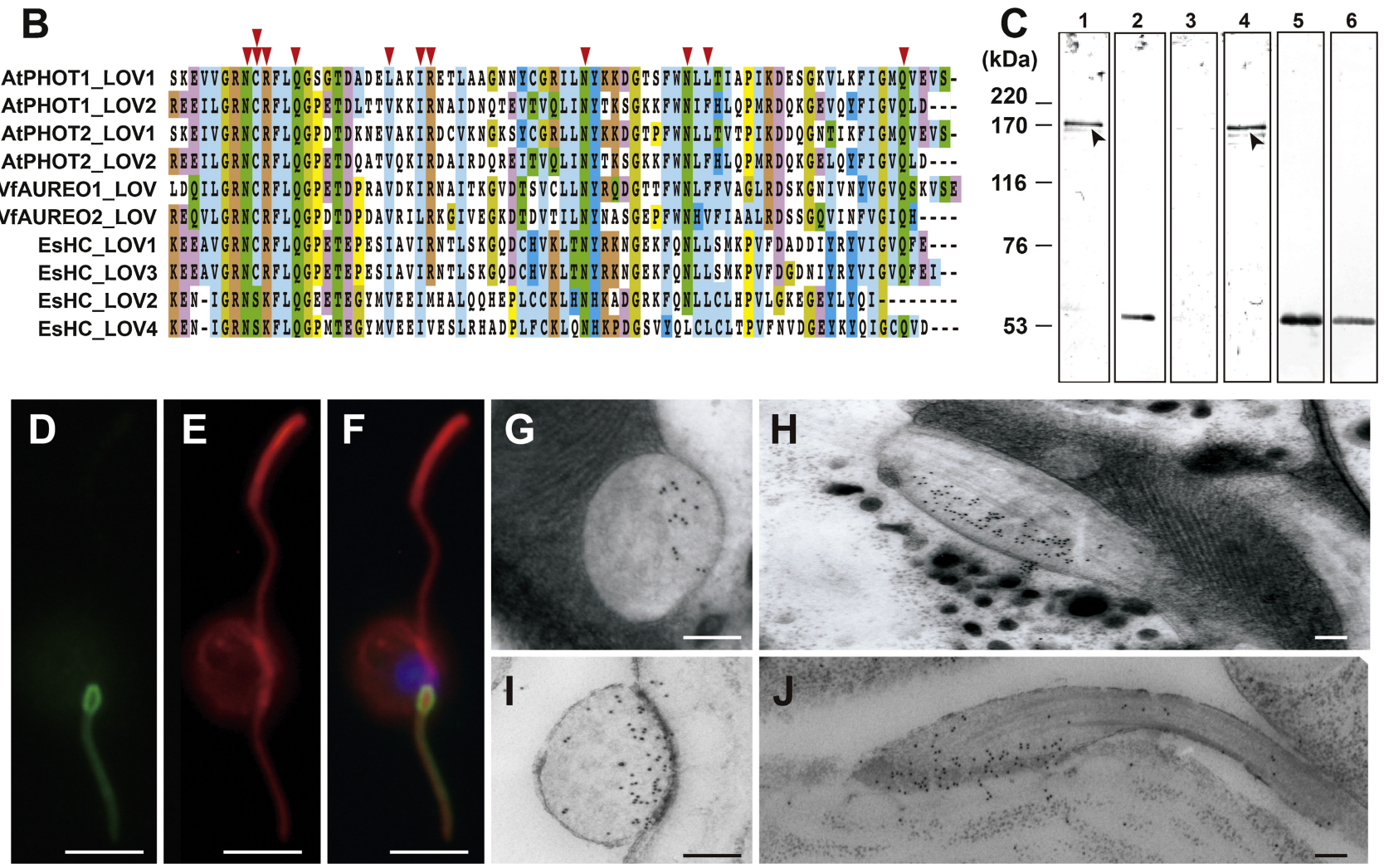

Figure 4. HELMCHROME, a candidate novel blue light receptor protein. A: Architecture of the conserved domains of HELMCHROME. The residue number from $\mathrm{N}$-terminus to $\mathrm{C}$-terminus shows the alignment for each domain. A part of the protein, from 661 to 1366 amino acids (indicated by the two-way arrow), was expressed in E. coli to raise the polyclonal antibody. B: Alignments of LOV domains of HELMCHROME, PHOTOTROPIN and AUREOCHROME. Conserved residues in each column are indicated by the same color. Arrowheads at the top show eleven residues necessary for FMN binding. Double arrowhead shows the cysteine residue, which is conserved in EsHC_LOV1 and EsHC_LOV3 but not in EsHC_LOV2 and EsHC_LOV4. AtPHOT, Arabidopsis thaliana PHOTOCHROPIN; VfAUREO, Vaucheria frigida AUREOCHROME; EsHC, Ectocarpus siliculosus HELMCHROME. C: Western blot analysis. Lane 1, both flagella (AF and PF) and anti-HELMCHROME antibody; Lane 2, both flagella (AF and PF) and anti-tubulin antibody; Lane 3, AF and anti-HELMCHROME antibody; Lane 4, PF and anti-HELMCHROME antibody; Lane 5, AF and anti-tubulin antibody; Lane 6, PF and anti-tubulin antibody. Arrowheads in Lane 1 and 4 indicate the detected HELMCHROME band. D-F: Immunofluorescence microscopy images of a plurizoid of $C$. bullosa treated with anti-HELMCHROME antibody (D), anti-tubulin antibody $(E)$ and merged with DAPI (F). Note that HELMCHROME is distributed along the entire length of the PF with an obvious accumulation at paraflagellar body. G-J: Immuno-electron micrographs of paraflagellar body of PF in Ectocarpus siliculosus (G, H) and Colpomenia bullosa (I, J). Anti-HELMCHROME antibody conjugated to $10 \mathrm{~nm}$ gold particles labels the crystalized material zone in paraflagellar body. Scale bars represent $5 \mu \mathrm{m}$ in (D-F) and $200 \mathrm{~nm}$ in (G-J).

(Fig. 4D-F) confirmed that HELMCHROME was localized along the length of PF with an accumulation at the paraflagellar body. Immunoelectron microscopy (Fig. 4G-J) revealed that
HELMCHROME was a major component of crystalized material, which is localized at the paraflagellar body and closely facing the eyespot (Fu et al. 2013). This subcellular localization 
supports a hypothesis that the eyespot has a concave mirror function to enhance the light detection of paraflagellar body during phototaxis (Kawai et al. 1990). It will require strict experimental evidence to elucidate the true function of HELMCHROME, however, based on its unique domain structure and subcellular localization, it is likely that HELMCHROME is the photoreceptor protein responsible for phototaxis in brown algal swarmers.

In summary, our data have presented a brown algal flagellar proteome database obtained by LCMS/MS analysis. To our knowledge, this is the first proteomics analysis of flagella in the stramenopiles. Analyses of the 495 flagellar proteins indicate that brown algal flagella are very complex organelles. In addition to axonemal and IFT proteins, various proteins involved in signal transduction and energy metabolism are included in the proteome. Comparisons between $\mathrm{CbFP}$ and the genomewide sequences of flagellated and non-flagellated species, and between CbFP and CrFP, have provided datasets to explore evolutionarily conserved flagellar proteins and brown algal-specific proteins. Identification of AF- and PF-specific proteins has provided candidate proteins for investigating the heterogeneity of the two flagella at the molecular level. Finally, HELMCHROME is considered to be a novel blue light receptor protein which is involved in phototaxis of brown algal swarmers.

\section{Methods}

Flagella isolation: Mature thalli of Colpomenia bullosa (Saunders) Yamada were collected at Charatsunai (42.03 N, 140.99 E), Muroran, Japan. They were thoroughly washed with autoclaved seawater and placed at $10^{\circ} \mathrm{C}$ under dark condition for one night. When the thalli were submerged in chilled seawater next day, a large number of motile cells were released into the seawater. The motile cells were collected by centrifugation at $3,000 \mathrm{rpm}$ for $3 \mathrm{~min}$. Two $\mathrm{ml}$ of flagellar isolation buffer (30 mM HEPES, $5 \mathrm{mM} \mathrm{MgSO}_{4}, 5 \mathrm{mM}$ EGTA, $25 \mathrm{mM} \mathrm{KCl}$, $1 \mathrm{M}$ sorbitol, $\mathrm{pH} 7.0$ ) were added to the swarmer pellet, and the cells were resuspended in the buffer by pipetting up and down. The suspension was then transferred into a $15 \mathrm{ml}$ glass tube and vortexed vigorously for $60-90 \mathrm{sec}$. In order to remove the cell bodies, the suspension was firstly centrifuged for 3 times (2000 rpm, $3 \mathrm{~min}$ for each). The supernatant obtained was transferred to a new tube and centrifuged for another 3 times at a higher speed (3000 rpm, $3 \mathrm{~min}$ for each). Finally, the supernatant was collected into a $1.5 \mathrm{ml}$ centrifuge tube and centrifuged at $15000 \mathrm{rpm}$ for $60 \mathrm{~min}$. The flagellar pellet was obtained after removing the supernatant. For isolating AF and PF separately, isolation buffer was added to the collected cell pellets and gently pipetted up and down for $60 \mathrm{sec}$ without vortexing. After this treatment, the AF was readily detached from the cell body while the PF was still remained undetached. The supernatant containing AF was transferred to a new glass tube and treated with the same flagellar isolation procedure as described above. Another $2 \mathrm{ml}$ of flagellar isolation buffer was added to the remained pellets, which contained the cells with only PF. Followed the same procedure as used for isolating both flagella, PF-enriched fractions could be obtained after the final centrifugation. All the centrifugations were performed at $4{ }^{\circ} \mathrm{C}$. The isolated flagella were stored at $-80^{\circ} \mathrm{C}$ until use.

Transmission electron microscopy (TEM): Isolated flagella were fixed with $2 \%$ glutaradehyde and $2 \%$ tannic acid in $0.1 \mathrm{M}$ cacodylate buffer ( $\mathrm{pH} 7.2$ ) for $90 \mathrm{~min}$ on ice. After washing with $0.1 \mathrm{M}$ cacodylate buffer, these samples were post-fixed with $2 \% \mathrm{OsO}_{4}$ in $0.1 \mathrm{M}$ cacodylate buffer on ice for $1 \mathrm{~h}$. Samples were dehydrated in an acetone series and embedded in Spurr's epoxy resin. Thin sections were stained with $4 \%$ uranyl acetate and lead citrate and observed with a JEM-1011 electron microscope (JEOL, Tokyo, Japan). Preparation for motile cell samples was done by freeze fixation and substitution protocols essentially as previously described (Fu et al. 2013; Nagasato and Motomura 2002).

Scanning electron microscopy (SEM): Male gametes liberated from gameteophytes of Ectocarpus siliculosus $32 \mathrm{~m}$ strain which were cultured in half-strength PESmedium (Provasoli 1968) under cool white fluorescent lamps (30$40 \mu \mathrm{mol}$ photons $\mathrm{m}^{-2} \cdot \mathrm{s}^{-1}$ ) at $15^{\circ} \mathrm{C}$ under long-day conditions (14 hr light: $10 \mathrm{hr}$ dark), were simultaneously fixed with $3 \mathrm{ml}$ glutaradehyde fixative ( $2 \%$ glutaradehyde, $0.1 \% \mathrm{CaCl}_{2}, 2 \% \mathrm{NaCl}$ in $0.1 \mathrm{M}$ cacodylate buffer) and $1 \mathrm{ml} \mathrm{OsO} 4$ fixative $\left(2 \%\right.$ in $\left.\mathrm{H}_{2} \mathrm{O}\right)$ for $15 \mathrm{~min}$. Fixed gametes were put on Omnipore membrane $(0.1 \mu \mathrm{m})$ (Merck Millipore, MA, USA) and washed with cacodylate buffer $\left(2 \% \mathrm{NaCl}, 0.1 \% \mathrm{CaCl}_{2}\right.$ in $0.1 \mathrm{M}$ cacodylate buffer). Samples were dehydrated in an acetone series, critical pointdried with HCP-2 (Hitachi, Tokyo, Japan), and finally coated with Au-Pd with E101 ion sputter (Hitachi, Tokyo, Japan). Images were taken by a JSM-6301F field-emission scanning electron microscope (JEOL, Tokyo, Japan) operating at $5 \mathrm{kV}$.

High-speed videography: Flagellar beat patterns of Ectocarpus siliculosus plurizoids were observed using a Zeiss microscope (Axio Vert.A1) under 40x objective. Videos were recorded with a frame rate of 600 frames per sec (fps) by a high-speed digital camera HAS220 (DITECT, Tokyo, Japan).

SDS-PAGE and 2-D gel electrophoresis: Isolated flagella were solubilized in SDS sample buffer $(50 \mathrm{mM}$ Tris- $\mathrm{HCl}, \mathrm{pH}$ $6.5,2 \%$ SDS, $10 \%$ glycerol, $3 \% \beta$-mercaptoethanol, $0.2 \%$ bromophenol blue) and a protein assay was carried out using the 2D Quant kit (GE Healthcare, Buckinghamshire HP7 9NA, England). Twenty $\mu \mathrm{g}$ of flagellar protein were loaded to $10 \%$ polyacrylamide gel and the gel was stained with Coomassie Brilliant Blue. For 2D analysis, flagellar proteins were rehydrated with $200 \mu \mathrm{l}$ of rehydration buffer (Urea, $8 \mathrm{M}, \mathrm{CHAPS}, 2 \%$, $0.5 \%$ IPG buffer $\mathrm{pH} 4-7,65 \mathrm{mM}$ DTT, 0.2\% bromophenol blue) and subsequently used for isoelectric focusing with an Immobiline DryStrip gels (IPG strips, pH 4-7, $11 \mathrm{~cm}$ ) (GE Healthcare). The IPGphor IEF System (GE Healthcare) was applied according to the manufacture protocol. Before the second dimension of the electrophoresis, the strip was equilibrated with equilibration buffer (50 mM Tris-HCl, pH 6.8, 6 M Urea, 30\% glycerol, 1\% DTT and $0.2 \%$ bromophenol blue) for $30 \mathrm{~min}$. Gels were stained by silver staining method after the second dimension electrophoresis and protein spots were analyzed using PDQuest software (Bio-Rad, Hercules, CA, USA).

In-gel digestion and LC-MS/MS: One-dimensional gels were excised and cut into 1-mm pieces and the proteins were reduced with $10 \mathrm{mM}$ dithiothreitol in $25 \mathrm{mM}$ ammonium bicarbonate $(A B C)$ solution and subsequently alkylated with $55 \mathrm{mM}$ iodoacetamide in $25 \mathrm{mM}$ ABC solution. Trypsin digestion was carried out for $14 \mathrm{~h}$ at $37^{\circ} \mathrm{C}$ and peptides were extracted with solutions of $50 \%$ acetonitrile (ACN) $/ 0.1 \%$ formic acid (FA), 
$100 \% \mathrm{ACN} / 0.1 \% \mathrm{FA}$ and $0.1 \% \mathrm{FA}$ in $\mathrm{H}_{2} \mathrm{O}$. The final elution volume was adjusted to $100 \mu \mathrm{l}$ by evaporation. All regents used were HPLC grade. Four $\mu$ l of tryptic digests were separated on a Paradigm MS2 HPLC (Bruker-Michrom, Aubum, CA, USA) equipped with an HTS-PAL auto-sample injection system (LEAP, Carrboro, NC, USA) on a nanocapillary column (0.1 mm- Inner Diameter $\times 50 \mathrm{~mm}$, Chemicals Evaluation and Research Institute, Tokyo, Japan). Solvent A consisted of $2 \%$ AN/0.1\% FA in $\mathrm{H}_{2} \mathrm{O}$, and solvent $\mathrm{B}$ consisted of $90 \% \mathrm{AN} / 0.1 \%$ $\mathrm{FA}$ in $\mathrm{H}_{2} \mathrm{O}$. The column elute was subjected into an LTQOrbitrap XL mass spectrometer (Thermo Scientific, Waltham, MA, USA) with nano-electrospray using a gradient system. During gradient analysis, a lock mass (m/z445) function was applied to obtain constant mass accuracy. MS/MS spectral data were analyzed using Thermo Proteome Discoverer version 1.2.0.208 with a Mascot search engine (Matrix Science, London W1U 7GB UK), using a translated dataset of the Ectocarpus genome. The parameters for data searching were set as following: peptide tolerance as $10 \mathrm{ppm}, \mathrm{MS} / \mathrm{MS}$ tolerance as $0.8 \mathrm{Da}$, dynamic modification of methionine oxidation and static modification of cysteine carbamidomethylation. Proteins were identified under FDR criteria of $P<0.05$. To reduce the number of redundant proteins, proteins that had shared peptides were grouped. Using three isolated flagellar preparations, the identifications were carried out separately for 3 times. Proteins identified by two or more peptides and found in 2 experiments were assigned to the Colpomenia bullosa flagellar proteome $(\mathrm{CbFP})$. Irrelevant proteins such as trypsin and keratins were excluded before analysis.

Protein analysis: Gene Ontology annotation and analysis were performed using the Blast2Go software (http://www.blast2go.com/b2ghome). Prediction of transmembrane helices was performed using the TMHMM Server (http://www.cbs.dtu.dk/services/TMHMM).

The strategy for searching orthologous proteins of brown algae flagellar proteome was modified from a previously described method (Broadhead et al. 2006). The genome translation data of 17 selected organisms (Aureococcus anophagefferens, Thalassiosira pseudonana, Phaeodactylum tricornutum, Phytophthora infestans, Chondrus crispus, Cyanidioschyzon merolae, Chlamydomonas reinhardtii, Micromonas pusilla, Ostreococcus tauri, Arabidopsis thaliana, Guillardia theta, Tetrahymena thermophila, Trypanosoma brucei, Schizosaccharomyces pombe, Batrachochytrium dendrobatidis, Strongylocentrotus purpuratus and Homo sapiens) were retrieved from the NCBI database (http://www.ncbi.nlm.nih.gov/genome). The genome data of Bigelowiella natans was retrieved from the JGI database (http://genome.jgi.doe.gov/Bigna1/Bigna1.home.html).

A local reciprocal blast application was developed using the BLAST+ version 2.2.26 obtained from NCBI (ftp://ftp.ncbi.nlm.nih.gov/blast/executables/blast+/LATEST).

First round blast was carried out to screen $495 \mathrm{CbFP}$ proteins against each organism's genome with an e-value cut off of $\leq$ $1 \mathrm{e}^{-10}$ and percentage of identical matches $\geq 30 \%$. If a best-hit sequence was found in the genome, the corresponding protein in CbFP was labeled in red in Supplementary Table S2; otherwise, query sequences that did not pass the e-value entry test were indicated in blue. The subsequent round of blast was performed with the same parameters using genome proteins as query sequences and CbFP as the subject sequences. Only the sequences of CbFP that passed the reciprocal blast, with query coverage $\geq 30 \%$ in the first round blast, were accepted as proteins with orthologs in one other genome, and these proteins were indicated in yellow. 657 flagellar protein sequences were obtained from the Chlamydomonas Flagellar Proteome
Database (http://labs.umassmed.edu/chlamyfp/index.php), the data of which was derived from another flagellar proteomics study (Pazour et al. 2005). The CbFP was compared with the 657 sequences by BLASTP with an e-value cut off of $\leq 1 \mathrm{e}^{-10}$.

Antibody generation: A polyclonal antibody was raised against HELMCHROME in two rabbits by injecting the antigen proteins expressed in E. coli. To prepare the antigen, axenic gametophytes of Ectocarpus siliculosus 32-strain were cultured in half-strength PES medium under cool white fluorescent lamps $\left(30-40 \mu \mathrm{mol}\right.$ photons $\left.\mathrm{m}^{-2} \cdot \mathrm{s}^{-1}\right)$, long-day condition (14 hr light: $10 \mathrm{hr}$ dark) at $15^{\circ} \mathrm{C}$. When thalli became sexually mature, total RNA of fresh algal material $(100 \mathrm{mg})$ was extracted using the RNeasy Mini Kit (Qiagen, Venlo, Netherlands). RT-PCR was performed using the RNA PCR kit (AMV) Ver.3.0 (Takara, Ohtsu, Japan). The open reading frame of HELMCHROME was amplified using nested PCR with primers HelmcF1 (5'GACCAGTATGGTCGGAAATTCG3') and HelmcR1 (5'GTT TTC CCA GTC ACG AC3') for first PCR, and HelmcF2 (5' GACCAGTATGGTCGGAAATTCG3') and HelmcR2 (5' CGTAGAGATGAGGTTATCCAGG3') for the second PCR. The nested PCR product was subcloned into a pT7Blue T-vector (Merck Millipore, MA, USA) and sequenced. A large fragment (2052 bp) of the gene encoding the protein region as indicated in Figure $4 \mathrm{~A}$ was amplified using primers HelmcF3 (5' CGGGGTACCATGGAACGAGTCCTG3') and HelmcR3 (5' CAATAGAGTCGACGAACATGTCGCTGA3'). Recombinant plasmid for protein expression was constructed by ligating the PCR product into pCold II DNA vector (TaKaRa), and both were digested with Kpnl and Sall enzymes. BL 21 cells (TaKaRa) were transformed with the recombinant plasmid. Protein expression and purification (His TALON Gravity Column purification kit, Clontech Laboratories, Mountain View, CA 94043 USA) were carried out according to the manufacture's protocols.

Western blot analysis: For Western Blot analysis, flagellar proteins were separated by SDS-PAGE $(7.5 \%$ gel), and the gel was electrotransferred onto a polyvinylidene fluoride (PVDF) membrane (ATTO, Tokyo, Japan). The membrane was cut into strips and blocked for $1 \mathrm{~h}$ with $1 \% \mathrm{BSA}$ and $5 \%$ skim milk in TTBS buffer $(0.1 \%$ Tween 20 in TBS). The rabbit polyclonal anti-HELMCHROME (diluted 1:5000) and mouse monoclonal anti- $\alpha$-tubulin (DM1A, diluted 1:3000, Sigma-Aldrich, St Louis, MO, USA) antibodies were used as primary antibodies. Secondary antibodies were anti-rabbit or -mouse IgG (Fc), alkaline phosphatase-conjugated antibodies (1:5000) (Promega, Madison, WS, USA). The color reaction was detected by a ProtoBlot II AP System kit (Promega) according to the manufacturer's instructions.

Immunofluorescence microscopy: $C$. bullosa plurizoids were preliminarily fixed in 3\% paraformaldehyde, $0.1 \%$ glutaradehyde and $2 \% \mathrm{NaCl}$ in PHEM buffer $(60 \mathrm{mM}$ PIPES, $25 \mathrm{mM}$ HEPES, $10 \mathrm{mM}$ EGTA, $2 \mathrm{mM} \mathrm{MgCl}_{2}, \mathrm{pH}$ 7.5) for $30 \mathrm{~min}$ on ice. Samples were mounted on poly-L-lysine coated cover glasses, treated with PBS containing 5\% Triton X100 for $30 \mathrm{~min}$ at room temperature and washed with PBS for three times. After an incubation in PBS containing $0.1 \%$ $\mathrm{NaBH}_{4}$ for $20 \mathrm{~min}$ at room temperature, the samples were washed 3 times with PBS and treated in blocking solution $(2.5 \%$ skim milk, $5 \%$ normal goat serum and $0.05 \%$ $\mathrm{NaN}_{3}$ in PBS) for $30 \mathrm{~min}$ at $37^{\circ} \mathrm{C}$. Then they were incubated with the polyclonal anti-HELMCHROME antibody (diluted 1:800 with PBS) and an anti-tubulin antibody (DM1A, diluted $1: 200$ with PBS, Sigma-Aldrich) overnight at $20^{\circ} \mathrm{C}$. Next, they were incubated with fluorescein isothiocyanate (FITC)conjugated goat anti-rabbit IgG (diluted 1:50, Sigma-Aldrich) and rhodamine-B-conjugated goat anti-mouse IgG (diluted 
1:50, Sigma-Aldrich) for $60 \mathrm{~min}$ at $37^{\circ} \mathrm{C}$. The nuclei were stained with $0.5 \mu \mathrm{g} / \mathrm{ml} 4^{\prime}$-6-diamidino-2-phenylindole (DAPI) for $10 \mathrm{~min}$ at room temperature. Finally, samples were mounted with Mowiol 4-88 mounting medium (Osborn and Weber 1982) containing $0.2 \% \mathrm{p}$-phenylenediamine, and observed with a BX50 fluorescence microscope (Olympus, Tokyo, Japan).

Immuno-electron microscopy: The plurilocular zoidangia of $E$. siliculosus and motile cells of $C$. bullosa were rapidly freezed in liquid propane and liquid nitrogen for $10 \mathrm{sec}$ in each, and then transferred to previously cooled ethanol and kept at $-80^{\circ} \mathrm{C}$ for $4 \mathrm{~d}$. The samples were kept at $-40{ }^{\circ} \mathrm{C}$ for $2 \mathrm{~h}$ and subsequently infiltrated with $25 \%, 50 \%, 75 \%$ and $100 \%$ of Lowicryl HM20 resin (Electron Microscopy Sciences, Hatfield, PA, USA) in ethanol $(\mathrm{v} / \mathrm{v})$ for $1 \mathrm{~h}$ in each concentration at $4{ }^{\circ} \mathrm{C}$. Finally, they were kept in fresh $100 \% \mathrm{HM} 20$ overnight at $-40^{\circ} \mathrm{C}$. Polymerization was carried out at $-40^{\circ} \mathrm{C}$ for $2 \mathrm{~d}$ and room temperature for $1 \mathrm{~d}$ under UV light. Thin sections were cut and mounted on a nickel slot grid, treated with blocking solution $(2.5 \%$ skim milk, $5 \%$ normal goat serum and $0.1 \% \mathrm{NaN}_{3}$ in PBS) for $1 \mathrm{~h}$ at room temperature, and subsequently incubated in the blocking solution containing 1:1000 diluted anti-HELMCHROME antibody for $12 \mathrm{~h}$ at $20^{\circ} \mathrm{C}$. After rinsing with PBS and water for several times, they were incubated with 1:50 diluted $10 \mathrm{~nm}$ colloidal gold-conjugated goat anti-rabbit IgG (BBI Solutions) in PBS for $1 \mathrm{~h}$ at room temperature. Finally, the thin sections were stained with TI blue (Nisshin EM, Tokyo, Japan) and lead citrate, and observed with a JEM-1011 electron microscope (JEOL, Tokyo, Japan).

\section{Acknowledgements}

We would like to thank Dr. Kazuo Inaba, Shimoda Marine Research Center, Tsukuba University, for his helpful advice on the flagellar proteomics analysis. This study was supported by a Grant-in-Aid for Scientific Research on Innovative Areas from the Ministry of Education, Culture, Sports, Science and Technology of Japan (24112701).

\section{Appendix A. Supplementary data}

Supplementary data associated with this article can be found, in the online version, at http://dx.doi.org/10.1016/j.protis.2014.07.007.

\section{References}

Avidor-Reiss T, Maer AM, Koundakjian E, Polyanovsky A, Keil T, Subramaniam S, Zuker CS (2004) Decoding cilia function: defining specialized genes required for compartmentalized cilia biogenesis. Cell 117:527-539

Baldauf SL (2008) An overview of the phylogeny and diversity of eukaryotes. J Syst Evol 46:263-273

Baron DM, Ralston KS, Kabututu ZP, Hill KL (2007) Functional genomics in Trypanosoma brucei identifies evolutionarily conserved components of motile flagella. J Cell Sci 120:478-491
Bisgrove BW, Yost HJ (2006) The roles of cilia in developmental disorders and disease. Development 133:4131-4143

Bloch MA, Johnson KA (1995) Identification of a molecular chaperone in the eukaryotic flagellum and its localization to the site of microtubule assembly. J Cell Sci 108:3541-3545

Broadhead R, Dawe HR, Farr H, Griffiths S, Hart SR, Portman N, Shaw MK, Ginger ML, Gaskell SJ, McKean PG, et al. (2006) Flagellar motility is required for the viability of the bloodstream trypanosome. Nature 440:224-227

Carvalho-Santos Z, Azimzadeh J, Pereira-Leal JB, Bettencourt-Dias M (2011) Tracing the origins of centrioles, cilia, and flagella. J Cell Biol 194:165-175

Cavalier-Smith T (2002) The phagotrophic origin of eukaryotes and phylogenetic classification of Protozoa. Int J Syst Evol Microbiol 52:297-354

Clayton MN (1989) Brown Algae and Chromophyte Phylogeny. In Green JC, Leadbeater BSC, Diver WL (eds) The Chromophyte Alge: Problems and Perspectives. Clarendon Press, Oxford, pp 229-254

Cock JM, Sterck L, Rouzé P, Scornet D, Allen AE, Amoutzias G, Anthouard V, Artiguenave F, Aury J-M, Badger JH, et al. (2010) The Ectocarpus genome and the independent evolution of multicellularity in brown algae. Nature 465:617-621

Crosson S, Moffat K (2001) Structure of a flavin-binding plant photoreceptor domain: insights into light-mediated signal transduction. Proc Natl Acad Sci USA 98:2995-3000

Crosson S, Rajagopal S, Moffat K (2003) The LOV domain family: photoresponsive signaling modules coupled to diverse output domains. Biochemistry 42:2-10

Davenport JR, Yoder BK (2005) An incredible decade for the primary cilium: a look at a once-forgotten organelle. Am J Physiol-Renal 289:F1159-F1169

Davy BE, Robinson ML (2003) Congenital hydrocephalus in hy3 mice is caused by a frameshift mutation in Hydin, a large novel gene. Hum Mol Genet 12:1163-1170

de Groot PWJ, Klis FM (2008) The conserved PA14 domain of cell wall-associated fungal adhesins governs their glycan-binding specificity. Mol Microbiol 68: $535-537$

Elias M, Archibald JM (2009) The RJL family of small GTPases is an ancient eukaryotic invention probably functionally associated with the flagellar apparatus. Gene 442:63-72

Fan Y, Esmail MA, Ansley SJ, Blacque OE, Boroevich K, Ross AJ, et al. (2004) Mutations in a member of the Ras superfamily of small GTP-binding proteins causes Bardet-Biedl syndrome. Nat Genet 36:989-993

Feng Y, Walsh CA (2004) The many faces of filamin: a versatile molecular scaffold for cell motility and signalling. Nat Cell Biol 6:1034-1038

Fliegauf M, Benzing T, Omran H (2007) When cilia go bad: cilia defects and ciliopathies. Nat Rev Mol Cell Biol 11:880-893

Flores-Moya A, Posudin YI, Fernández JA, Figueroa FL, Kawai H (2002) Photomovement of the swarmers of the brown algae Scytosiphon lomentaria and Petalonia fascia: effect of photon irradiance, spectral composition and UV dose. J Photochem Photobiol B 66:134-140 
Fu G, Nagasato C, Ito T, Müller DG, Motomura T (2013) Ultrastructural analysis of flagellar development in plurilocular sporangia of Ectocarpus siliculosus (Phaeophyceae). Protoplasma 250:261-272

Fujita S, Iseki M, Yoshikawa S, Makino Y, Watanabe M, Motomura T, Kawai H, Murakami A (2005) Identification and characterization of a fluorescent flagellar protein from the brown alga Scytosiphon lomentaria (Scytosiphonales, Phaeophyceae): A flavoprotein homologous to Old Yellow Enzyme. Eur J Phycol 40:159-167

Geer LY (2002) CDART: protein homology by domain architecture. Genome Res 12:1619-1623

Geller A, Müller DG (1981) Analysis of the flagellar beat pattern of male Ectocarpus siliculosus gametes (Phaeophyta) in relation to chemotactic stimulation by female cells. J Exp Biol 92:53-66

Gherman A, Davis EE, Katsanis N (2006) The ciliary proteome database: an integrated community resource for the genetic and functional dissection of cilia. Nat Genet 38:961-962

Ginger ML, Portman N, McKean PG (2008) Swimming with protists: perception, motility and flagellum assembly. Nat Rev Microbiol 6:838-850

Govorunova EG, Jung KH, Sineshchekov OA, Spudich JL (2004) Chlamydomonas sensory rhodopsins A and B: cellular content and role in photophobic responses. Biophys $\mathrm{J}$ 86:2342-2349

Guiry MD, Guiry GM (2014) AlgaeBase. World-wide electronic publication, National University of Ireland, Galway. http://www.algaebase.org

Henry EC, Cole KM (1982a) Ultrastructure of swarmers in the Laminariales (Phaeophyceae). I. Zoospores. J Phycol 18:550-569

Henry EC, Cole KM (1982b) Ultrastructure of swarmers in the Laminariales (Phaeophyceae). II. Sperms. J Phycol 18:570-579

Idei M, Osada K, Sato S, Nakayama T, Nagumo T, Mann DG (2013) Sperm ultrastructure in the diatoms Melosira and Thalassiosira and the significance of the $9+0$ configuration. Protoplasma 250:833-850

Inglis P, Boroevich K, Leroux M (2006) Piecing together a ciliome. Trends Genet 22:491-500

Judelson HS, Shrivastava J, Manson J (2012) Decay of genes encoding the oomycete flagellar proteome in the downy mildew Hyaloperonospora arabidopsidis. PLoS ONE 7:e47624

Kawai H (1988) A flavin-like autofluorescent substance in the posterior flagellum of golden and brown algae. J Phycol 24:114-117

Kawai H (1992) Green flagellar autofluorescence in brown algal swarmers and their phototactic responses. Bot Mag Tokyo 105:171-184

Kawai H, Inouye I (1989) Flagellar autofluorescence in forty-four chlorophyll c-containing algae. Phycologia 28:222-227

Kawai H, Müller D, Fölster E, Häder D-P (1990) Phototactic responses in the gametes of the brown alga, Ectocarpus siliculosus. Planta 182:292-297
Kawai H, Nakamura S, Mimuro M, Furuya M, Watanabe M (1996) Microspectrofluorometry of the autofluorescent flagellum in phototactic brown algal zoids. Protoplasma 191: 172-177

Koide A, Bailey CW, Huang X, Koide S (1998) The fibronectin type III domain as a scaffold for novel binding proteins. $\mathrm{J} \mathrm{Mol}$ Biol 284:1141-1151

Kozminski KG, Johnson KA, Forscher P, Rosenbaum JL (1993) A motility in the eukaryotic flagellum unrelated to flagellar beating. Proc Natl Acad Sci USA 90:5519-5523

Lechtreck K-F, Witman GB (2007) Chlamydomonas reinhardtii hydin is a central pair protein required for flagellar motility. $\mathrm{J}$ Cell Biol 176:473-482

Li JB, Gerdes JM, Haycraft CJ, Fan Y, Teslovich TM, May-Simera H, Li H, Blacque OE, Li L, Leitch CC, et al. (2004) Comparative genomics identifies a flagellar and basal body proteome that includes the BBS5 human disease gene. Cell 117:541-552

Lorenzetti D, Bishop CE, Justice MJ (2004) Deletion of the Parkin coregulated gene causes male sterility in the quakingviable mouse mutant. Proc Natl Acad Sci USA 101: 8402-8407

Losi A, Gärtner W (2012) The evolution of flavin-binding photoreceptors: an ancient chromophore serving trendy blue-light sensors. Annu Rev Plant Biol 63:49-72

Mahjoub MR, Trapp ML, Quarmby LM (2005) NIMA-related kinases defective in murine models of polycystic kidney diseases localize to primary cilia and centrosomes. J Am Soc Nephrol 16:3485-3489

Maier I (1997a) The fine structure of the male gamete of Ectocarpus siliculosus (Ectocarpales. Phaeophyceae). I. General structure of the cell. Eur J Phycol 32: 241-325

Maier I (1997b) The fine structure of the male gamete of Ectocarpus siliculosus (Ectocarpales. Phaeophyceae). II. The flagellar apparatus. Eur J Phycol 32:255-266

Manton I, Clarke B (1951) Electron microscope observations on the zoospores of Pylaiella and Laminaria. J Exp Bot 2:242-243

Manton I, Clarke B, Greenwood AD (1953) Further observations with the electron microscope on spermatozoids in the brown algae. J Exp Bot 4:319-329

Marshall WF (2008) The cell biological basis of ciliary disease. J Cell Biol 180:17-21

Marshall WF, Nonaka S (2006) Cilia: Tuning in to the cell's antenna. Curr Biol 16:R604-R614

Matsunaga S, Uchida $H$, Iseki M, Watanabe M, Murakami A (2010) Flagellar motions in phototactic steering in a brown algal swarmer. Photochem Photobiol 86:374-381

Mitchell DR (2007) The evolution of eukaryotic cilia and flagella as motile and sensory organelles. Adv Exp Med Biol 607:130-140

Mitchell BF, Pedersen LB, Feely M, Rosenbaum JL, Mitchell DR (2005) ATP production in Chlamydomonas reinhardtii flagella by glycolytic enzymes. Mol Biol Cell 16: 4509-4518 
Müller DG, Maier I, Müller H (1987) Flagellum autofluorescence and photoaccumulation in heterokont algae. Photochem Photobiol 46:1003-1008

Nagarkatti-Gude DR, Jaimez R, Henderson SC, Teves ME, Zhang Z, Strauss JF (2011) Spag16, an axonemal central apparatus gene, encodes a male germ cell nuclear speckle protein that regulates SPAG16 mRNA expression. PLoS ONE 6:e20625

Nagasato C, Motomura T (2002) Influence of the centrosome in cytokinesis of brown algae: polyspermic zygotes of Scytosiphon lomentaria (Scytosiphonales, Phaeophyceae). J Cell Sci 115:2541-2548

Nicastro D, McIntosh JR, Baumeister W (2005) 3D structure of eukaryotic flagella in a quiescent state revealed by cryo-electron tomography. Proc Nat Acad Sci USA 102:15889-15894

O'Kelly CJ (1989) The Evolutionary Origin of the Brown Algae: Information from Studies of Motile Cell Ultrastructure. In Green JC, Leadbeater BSC, Diver WL (eds) The Chromophyte Algae: Problems and Perspectives. Oxford University Press, Oxford, pp 255-278

Okita N, Isogai N, Hirono M, Kamiya R, Yoshimura K (2005) Phototactic activity in Chlamydomonas "non-phototactic" mutants deficient in $\mathrm{Ca}^{2+}$-dependent control of flagellar dominance or in inner-arm dynein. J Cell Sci 118:529-537

Osborn M, Weber K (1982) Immunofluorescence and Immunocytochemical Procedures with Affinity Purified Antibodies: Tubulin-containing Structures. In Wilson L (ed) Methods in Cell Biology 24. Academic Press, New York, pp 97-132

Pazour GJ, Bloodgood RA (2008) Targeting proteins to the ciliary membrane. Curr Top Dev Biol 85:115-149

Pazour GJ, Agrin N, Leszyk J, Witman GB (2005) Proteomic analysis of a eukaryotic cilium. J Cell Biol 170:103-113

Provasoli L (1968) Media and Prospects for the Cultivation of Marine Algae. In Watanabe A, Hattori A (eds) Culture and Collection of Algae. Proc US - Japan Conf, Hakone, Sep 1996, Jan Soc Plant Physiol, pp 63-75.

Ralston KS, Kabututu ZP, Melehani JH, Oberholzer M, Hill KL (2009) The Trypanosoma bruceiflagellum: moving parasites in new directions. Annu Rev Microbiol 63:335-362

Rosenbaum JL, Witman GB (2002) Intraflagellar transport. Nat Rev Mol Cell Biol 3:813-825
Shapiro J, Ingram J, Johnson KA (2005) Characterization of a molecular chaperone present in the eukaryotic flagellum. Eukaryot Cell 4:1591-1594

Silberfeld T, Leigh JW, Verbruggen H, Cruaud C, De Reviers B, Rousseau F (2010) A multi-locus time-calibrated phylogeny of the brown algae (Heterokonta, Ochrophyta, Phaeophyceae): Investigating the evolutionary nature of the "brown algal crown radiation". Mol Phylogenet Evol 56:659-674

Stephens RE, Lemieux NA (1999) Molecular chaperones in cilia and flagella: implications for protein turnover. Cell Motil Cytoskeleton 44:274-283

Tombes RM, Shapiro BM (1985) Metabolite channeling: a phosphorylcreatine shuttle to mediate high energy phosphate transport between sperm mitochondrion and tail. Cell 41:325-334

Tombes RM, Brokaw C, Shapiro BM (1987) Creatine kinasedependent energy transport in sea urchin spermatozoa. Flagellar wave attenuation and theoretical analysis of high energy phosphate diffusion. Biophys J 52:75-86

Tuson M, He M, Anderson KV (2011) Protein kinase A acts at the basal body of the primary cilium to prevent Gli2 activation and ventralization of the mouse neural tube. Development 138:4921-4930

Varmuza S, Jurisicova A, Okano K, Hudson J, Boekelheide K, Shipp EB (1999) Spermiogenesis is impaired in mice bearing a targeted mutation in the protein phosphatase 1cgamma gene. Devel Biol 205:98-110

Woodland HR, Fry AM (2008) Pix proteins and the evolution of centrioles. PLOS ONE 3:e3778

Wothe DD, Charbonneau H, Shapiro BM (1990) The phosphocreatine shuttle of sea urchin sperm: flagellar creatine kinase resulted from a gene triplication. Proc Natl Acad Sci USA 87:5203-5207

Zhang Z, Kostetskii I, Moss SB, Jones BH, Ho C, Wang $\mathbf{H}$, et al. (2004) Haploinsufficiency for the murine orthologue of Chlamydomonas PF20 disrupts spermatogenesis. Proc Natl Acad Sci USA 101:12946-12951

Zhang Z, Sapiro R, Kapfhamer D, Bucan M, Bray J, Chennathukuzhi V, et al. (2002) A sperm-associated WD repeat protein orthologous to Chlamydomonas PF20 associates with Spag6, the mammalian orthologue of Chlamydomonas PF16. Mol Cell Biol 22:7993-8004 